\title{
The origin of pesisir cattle based on D-loop mitochondrial DNA
}

\author{
ANZALIA EKA PUTRI, ACHMAD FARAJALLAH, DYAH PERWITASARI ${ }^{*}$ \\ Department of Biology, Faculty of Mathematics and Natural Sciences, Institut Pertanian Bogor. Jl. Raya Dramaga, Bogor 16680, West Java, Indonesia \\ Tel.: +62-251-8622833, `email: witafar@gmail.com, witafar@apps.ipb.ac.id, anzaputri.27@gmail.com
}

Manuscript received: 8 July 2019. Revision accepted: 20 August 2019.

\begin{abstract}
Putri AE, Farajallah A, Perwitasari D. 2019. The origin of pesisir cattle based on D-loop mitochondrial DNA. Biodiversitas 20: 2569-2575. Pesisir cattle is one of Indonesia's local cattle descended from Bos indicus which has small body characteristics. It was assumed due to crossbreeding between pesisir cattle and other cattle. Therefore this study aims to study the origin of pesisir cattle based on the D-loop mtDNA region and to find out the phylogenetic relationships between pesisir cattle and other cattle. Cattle blood samples were taken in two locations, Krui Way and Tanah Rekah. Amplification of the mitochondrial gene using the primary pair of collections of Dr. Achmad Farajallah, namely AF22 (forward) 5'-GCGTACGCAATCTTACGATCA-3' and AF23 (reverse) 5'ATGCAGTTAAGTCCAGCTAC-3'. Reconstruction of phylogenetic trees was analyzed using the Neighbor-Joining Method based on Kimura 2 Parameters. The results of the mtDNA analysis in the D-loop region showed that there were two broods in pesisir cattle, namely Bos indicus and Bos javanicus. The closeness between these species is due to the close geographical distance between Bos indicus originating from Way Krui, Lampung and Bos javanicus from Java.
\end{abstract}

Keywords: Bos indicus, DNA, D-Loop, mitochondria, pesisir cattle

\section{INTRODUCTION}

Cattle are one of the domesticated livestock. The domestication of cattle started 8.000-10.000 year ago. It derived from auroch descendant (Bos primigenius) from Africa and distributed to Europa-Asia (Martinez-Navarro 2014). There are two types of modern cattle derived from Bos primigenius; those are humpless cattle (Bos taurus) and humped cattle (Bos indicus) (Troy 2001). Other than that, there is also Bos javanicus, which is descendant of Bibos banteng. Bos javanicus is one of the native Indonesian cattle, which is different from $B$. taurus and $B$. indicus (Nijman et al. 2003). One descendant of $B$. javanicus is an Indonesian Bali Cattle that distribute in all over Indonesia (Uggla 2008). There are also several types of domestic cattle in Indonesia, such as Aceh Cattle, Madura Cattle, and Pesisir Cattle (Martojo 2003).

Characteristics of pesisir cattle are unique. They have smaller body size than other cattle, short limb, slender legs and possessed small hump in the back. Pesisir cattle have monochrome color in body pattern that can be divided into red brick, yellow, brown, black, and white (Sarbaini 2004). West Sumatra society called pesisir cattle as Jawi Ratuih or Bantiang Ratuih, means cattle that breed once every year and have a lower price due to body size (Saladin 1983). Male pesisir cattle (age 4-6) have bodyweight around 160 kilograms, much lighter than that of Bali cattle (310 kilograms), PO cattle $(388 \mathrm{~kg})$, Aceh cattle $(302 \mathrm{~kg})$ and Madura cattle (248 kg) (Adrial 2010). The small weight may be caused by several causes, such as maintenance and feeding methods or crossbreeding between pesisir cattle and other cows.

Crossbreeding in pesisir cattle and other cows can occur because of the coexistence of the cattle in one area. The molecular method is one approach to study the crossbreeding. Various types of DNA markers can be used to understand the crossbreeding process. One of them is Mitochondrial DNA (Bradley 1996). Mitochondrial DNA was maternally inherited and showed a small amount of recombination, so it can be used to study the matrilineal genealogy of a species or between populations (Duryadi 1994). The most varied areas of mitochondrial DNA are the D-loop region (Pénzes et al. 2002). The D-loop region, which has a fairly high base variation, is located outside the segment that has a function of transcription and replication so it can be used to find out the pedigree of an animal and kinship (phylogenetic) (Mannen et al. 1998). Based on $D$ loop, Madura cattle showed two branches in phylogeny trees. Those are B. indicus and B. javanicus branch (Firdhausi 2010). Until now, there is no information about the phylogenetic relationship between Pesisir cattle ( $B$. indicus) and other cattle using D-loop marker.

This study aimed to determine the origin of pesisir cattle based on mtDNA in D-loop region and evaluate the phylogenetic relationship between pesisir cattle and other cattle.

\section{MATERIALS AND METHODS}

\section{Blood sample collection}

This study was conducted in Way Krui Lampung and Tanah Rekah Bengkulu. The blood sample was taken using syringe by injecting it to the neck and tail parts. The volume of the blood sample was taken about 1.5-2 $\mathrm{ml}$ and was put in the vacutainer tube $15 \mathrm{ml}$. Then, it was preserved using alcohol $70 \%$ minimum two times the volume of the blood sample. There were 32 samples; those 
consisted of 14 samples from Way Krui Lampung and 18 samples from Tanah Rekah Bengkulu (Table 1).

\section{Total DNA isolation}

The DNA was extracted using Genomic DNA mini kit Geneaid. This procedure followed the instruction from the Genomic DNA mini kit Geneaid (Geneaid Biotech Ltd., Taiwan)

\section{mtDNA amplification in the D-loop region}

The mitochondrial DNA amplification used a pair of primer from Dr. Achmad Farajallah collection, i.e., AF22 (forward) 5'-GCGTACGCAATCTTACGATCA-3' and AF23 (reverse) 5'-ATGCAGTTAAGTCCAGCTAC-3. The AF22 primer attaches to base 14979, and the primer AF23 attaches the base 16098 in Bos indicus (access number AF492350). In this amplification process, the size of the mtDNA that was targeted was $1120 \mathrm{bp}$. The pair of primers AF22 and AF23 located in the middle until the end of the DNA. This process used the PCR (Polymerase Chain Reaction) technique.

The composition of $25 \mathrm{ml} \mathrm{PCR}$ reaction was $1 \mathrm{ml}$ (10$100 \mathrm{ng}$ ) of DNA sample, 1.25 unit of RBC Bioscience Taq polymerase and its buffer system, $1 \mathrm{ml}$ dNTP ten nmol, 2 $\mathrm{ml} \mathrm{MgCl}$ 2, $1 \mathrm{ml}$ primers AF22 and AF23, and DW sterile. All the compositions were mixed and then put in to the PCR tube. It was centrifuged in $300 \mathrm{rpm}$ in 30 seconds. The result was amplificated in the Thermal Cycler TAKARA MP4 machine.

This procedure followed Firdhausi (2010) with some modification for the amplification process. We used $94^{\circ} \mathrm{C}$ for 5 minutes for pre-denaturation, $94^{\circ} \mathrm{C}$ for 1 minute for denaturation, $60^{\circ} \mathrm{C}$ for 1 minute for annealing, and $64^{\circ} \mathrm{C}$ for 1 minute for extension and was repeated for 30 cycles. The PCR reaction was ended with polymerization (final extension) at $72^{\circ} \mathrm{C}$ for 2 minutes. The PCR product was visualized using electrophoresis gel technique with composition $6 \%$ polyacrylamide (PAGE) in 5xTBE (10 mM Tris-HCL, $1 \mathrm{M}$ boric acid, 0.1 mM EDTA) buffer. The electrophoresis was run in $200 \mathrm{~V}$ for 45 minutes. The process then was continued with silver sensitive coloring (Tegelstrom 19869) with a little modification.

\section{DNA sequencing}

The amplification products that showed double bands were purified and being the templates in PCR reactions for nucleotide sequencing. The primers were used in the PCR process were the same as the primers were used for amplification. The PCR reaction was carried out using the Dideoxi Terminator method with labeled dNTP (big dye terminator). Nucleotide sequencing used sequencing services of First BASE Laboratories Sdn Bhd (Malaysia).

Table 1. Samples collection list

\begin{tabular}{|c|c|c|c|}
\hline $\begin{array}{l}\text { Sample } \\
\text { number }\end{array}$ & Location & Gender & Ages \\
\hline 01 & Way Krui & Female & Adult \\
\hline 03 & Way Krui & Female & Adult \\
\hline 05 & Way Krui & Female & Adult \\
\hline 07 & Way Krui & Female & Juvenile \\
\hline 08 & Way Krui & Female & Adult \\
\hline 09 & Way Krui & Female & Adult \\
\hline 10 & Way Krui & Female & Adult \\
\hline 11 & Way Krui & Female & Adult \\
\hline 13 & Way Krui & Female & Juvenile \\
\hline 14 & Way Krui & Female & Adult \\
\hline 15 & Way Krui & Female & Juvenile \\
\hline 16 & Way Krui & Female & Adult \\
\hline 17 & Way Krui & Female & Adult \\
\hline 18 & Way Krui & Female & Adult \\
\hline 19 & Way Krui & Female & Adult \\
\hline 21 & Tanah Rekah & Female & Adult \\
\hline 22 & Tanah Rekah & Female & Adult \\
\hline 23 & Tanah Rekah & Male & Juvenile \\
\hline 25 & Tanah Rekah & Female & Juvenile \\
\hline 26 & Tanah Rekah & Male & Juvenile \\
\hline 27 & Tanah Rekah & Female & Adult \\
\hline 28 & Tanah Rekah & Female & Adult \\
\hline 29 & Tanah Rekah & Female & Adult \\
\hline 30 & Tanah Rekah & Female & Adult \\
\hline 31 & Tanah Rekah & Female & Adult \\
\hline 32 & Tanah Rekah & Female & Juvenile \\
\hline 33 & Tanah Rekah & Female & Adult \\
\hline 34 & Tanah Rekah & Female & Juvenile \\
\hline 35 & Tanah Rekah & Female & Juvenile \\
\hline 36 & Tanah Rekah & Female & Adult \\
\hline 37 & Tanah Rekah & Female & Juvenile \\
\hline 38 & Tanah Rekah & Female & Juvenile \\
\hline
\end{tabular}

Table 2. Reference to mitochondrial DNA in several cattle species

\begin{tabular}{lllll}
\hline Accession number & Species & Strains & Localisation & References \\
\hline AB915322 & Bos javanicus lowi & Borneo banteng & Malaysia & Matsubayashi et al. (2014) \\
JN632605 & Bos javanicus Card4 & Banteng & Cambodia & Hassanin and Ropiquet (2007) \\
JN632606 & Bos javanicus CERZA & Javan banteng & Indonesia & Hassanin and Ropiquet (2007) \\
NC005971 & Bos indicus & Zebu cattle & Brazil & Tripathi et al. (2011) \\
NC006380 & Bos grunniens & Domestic yak & China & San et al. (2007) * \\
NC006853 & Bos Taurus & Taurine cattle & Korea & Chung and Ha (2004)* \\
NC013996 & Bos primigenius & Aurochs & Ireland & Edwards et al. (2010) \\
NC024818 & Bos gaurus & Gaur & France & Hassanin et al. (2012) \\
NC025563 & Bos mutus & Wild yak & China & Na et al. (2014) \\
NC036020 & Bos frontalis & Gayal & China & Wang and Zeng (2017) \\
\hline
\end{tabular}

Note: $(*)$ personal communication 
The results of nucleotide sequencing were edited using Bio Edit version 7.2.5 program. The edited DNA sequence was aligned using Clustal $\mathrm{W}$ included in the MEGA version 6.0 program (Tamura et al. 2013) with several DNA sequences from the Bovidae group published in GenBank (http://ncbi.nlm.nih.gov). All DNA sequences were paralleled by involved several homologous DNA references in public data (NCBI) (Table 2).

The analysis included calculating nucleotide composition and genetic distance based on the D-loop segment. The calculation value of genetic distance was based on the Kimura-2-parameter (K2P) substitution model. The phylogeny tree was reconstructed using the bootstrapped Neighbor-Joining (NJ) method with 1000 repetitions (Nei and Kumar 2000).

\section{RESULTS AND DISCUSSION}

\section{Amplification and sequencing products}

There were 32 samples obtained from two locations of study, Way Krui (WK), Lampung and Tanah Rekah (TR), Bengkulu. The amplified D-loop sequence showed varying results. The result lengths were around $740 \mathrm{bp}$ for pesisir samples, except for pesisir cattle samples of WK 01 and WK 13 that were around $886 \mathrm{bp}$. Some of the sample numbers were not included in the next analysis due to it was not had good enough quality of bands. The sample was assumed will produce less validity of nucleotide sequence. From sequencing results, there were found that the amplified D-loop sequence showed varying results. The results of nucleotide sequences of pesisir cattle were according to the primer design, AF 22 - AF 23 consisted of $291 \mathrm{bp}$ Cyt b gene, 70 bp of tRNA Thr gene, $65 \mathrm{bp}$ of tRNA Pro gene, and 740-886 bp of D-loop (Figure 1).

The result lengths were around $740 \mathrm{bp}$ for pesisir samples, except for pesisir cattle samples of WK 01 and WK 13 that were around $886 \mathrm{bp}$. The length of $D$-loop section that was used in the alignment process with related species was around $740 \mathrm{bp}$ for pesisir cattle sample TR and WK, but for sample WK 01 and WK 03 were around 886 bp.

The average of nucleotide compositions in pesisir cattle samples from both locations consisted of $25.8 \% \mathrm{~T}$ base, $25.9 \% \mathrm{C}$ base, $33.5 \% \mathrm{~A}$ base, and $14.8 \% \mathrm{G}$ base. The most basic components that were found in pesisir cattle were A and $\mathrm{T}$ base with $59.3 \%$, while $\mathrm{G}$ and $\mathrm{C}$ base was $40.7 \%$. The base sequence of four fragments was divided into conserve and variables. Different bases consist of two types called parsimony bases and single (singleton) bases (Table 3).

\section{Nucleotide mutations and phylogeny analysis based on the $D$-loop sequence}

D-loop sequence of pesisir cattle had various lengths. The variation was due to insertion and deletion process. Within pesisir cattle, we found base nucleotide with a length of $22 \mathrm{nt}$ that had tandem repeat repetition. The repeated motives that appeared were GTACATAATATTA and ATGTAATAA. Repeated motives that appeared in genus Bos were always started with GTAAT. Repeat segments were found in species B. javanicus and Lampung WK 01 and WK 03 samples. Repeat segments in $B$. javanicus and pesisir cattle sample of WK 01 were repeated for eight times, while in pesisir cattle sample of WK 13 were repeated for seven times. There were no repeated segments in $B$. indicus and other samples of pesisir cattle such as pesisir cattle number WK 19, TR 21, and TR 29 (Figure 2).

Substitution, both transitions, and transversion, often occurred in D-loop sequence. The phylogeny topology based on the D-loop sequence showed there were two groupings of pesisir cattle against $B$. indicus Pesisir cattle that were grouped with B. indicus had $66 \%$ bootstrap. Pesisir cattle sample of WK 01 and WK 13 were grouped with B. javanicus CERZA showed $100 \%$ bootstrap for WK 13 and $83 \%$ for WK 01 . Other than WK 01 and WK 13 sample, there were no specific grouping patterns in the formed phylogeny tree. Pesisir cattle sample of WK and TR codes tend to gather randomly between locations groups.

Table 3. The same number of bases and different bases in the four mtDNA segments

\begin{tabular}{lccc}
\hline \multirow{2}{*}{ Fragments } & $\begin{array}{c}\text { Conserve } \\
\text { bases }\end{array}$ & \multicolumn{2}{c}{ Different bases } \\
\cline { 3 - 4 } & 234 & Parsimony & Singleton \\
\hline Cyt B & 63 & 45 & 11 \\
tRNA Thr & 59 & 6 & 0 \\
tRNA Pro & 680 & 140 & 0 \\
D-loop & & & 39 \\
\hline
\end{tabular}

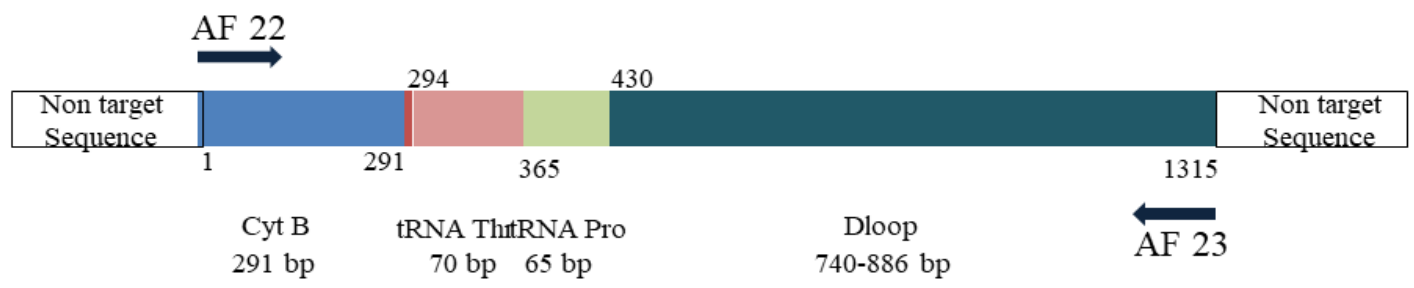

Figure 1. Products resulting from tracing based on primary design AF 22-AF 23 (bp) base pair 


\begin{tabular}{|c|c|c|c|c|c|c|c|c|c|c|c|c|c|c|c|c|c|c|c|c|c|c|c|c|c|c|c|c|c|c|c|c|c|c|c|c|c|c|}
\hline & $\begin{array}{l}6 \\
0 \\
4\end{array}$ & $\begin{array}{l}6 \\
0 \\
5\end{array}$ & $\begin{array}{l}6 \\
0 \\
6\end{array}$ & $\begin{array}{l}6 \\
0 \\
7\end{array}$ & $\begin{array}{l}6 \\
0 \\
0\end{array}$ & $\begin{array}{l}6 \\
0 \\
0\end{array}$ & $\begin{array}{l}6 \\
1 \\
0\end{array}$ & $\begin{array}{l}6 \\
1 \\
1\end{array}$ & $\begin{array}{l}6 \\
1 \\
2\end{array}$ & $\begin{array}{l}6 \\
1 \\
3\end{array}$ & $\begin{array}{l}6 \\
1 \\
4\end{array}$ & $\begin{array}{l}6 \\
1 \\
5\end{array}$ & $\begin{array}{l}6 \\
1 \\
6\end{array}$ & $\begin{array}{l}6 \\
1 \\
7\end{array}$ & $\begin{array}{l}6 \\
1 \\
8\end{array}$ & $\begin{array}{l}6 \\
1 \\
9\end{array}$ & $\begin{array}{l}6 \\
2 \\
0\end{array}$ & $\begin{array}{l}6 \\
2 \\
1\end{array}$ & $\begin{array}{l}6 \\
2 \\
2\end{array}$ & $\begin{array}{l}6 \\
2 \\
3\end{array}$ & $\begin{array}{l}6 \\
2 \\
4\end{array}$ & $\begin{array}{l}6 \\
2 \\
5\end{array}$ & $\begin{array}{l}6 \\
2 \\
6\end{array}$ & $\begin{array}{l}6 \\
2 \\
7\end{array}$ & $\begin{array}{l}6 \\
2 \\
B\end{array}$ & $\begin{array}{l}6 \\
2 \\
9\end{array}$ & $\begin{array}{l}6 \\
3 \\
0\end{array}$ & $\begin{array}{l}6 \\
3 \\
1\end{array}$ & $\begin{array}{l}6 \\
3 \\
2\end{array}$ & $\begin{array}{l}6 \\
3 \\
3\end{array}$ & $\begin{array}{l}6 \\
3 \\
4\end{array}$ & $\begin{array}{l}6 \\
3 \\
5\end{array}$ & $\begin{array}{l}6 \\
3 \\
6\end{array}$ & $\begin{array}{l}6 \\
3 \\
7\end{array}$ & $\begin{array}{l}6 \\
3 \\
B\end{array}$ & & & $\begin{array}{l}6 \\
4 \\
0\end{array}$ \\
\hline & 4 & 5 & 6 & 7 & $\mathrm{~B}$ & 9 & 0 & 1 & 2 & 3 & 4 & 5 & & & & & & & & & & & & & & 9 & D & 1 & 2 & 3 & 4 & 5 & 6 & 7 & B & & & \\
\hline $\begin{array}{l}\text { AB915322 jaranicus } \\
\text { lowi }\end{array}$ & c & $\mathrm{T}$ & $\mathbf{T}$ & $\mathrm{c}$ & $\mathbf{A}$ & - & - & $\mathrm{c}$ & $\mathbf{A}$ & $G$ & c & - & - & - & - & - & - & - & - & - & - & - & - & - & - & - & - & - & - & - & - & - & - & - & - & & & - \\
\hline JN632605 jaranicus & A & c & A & - & c & $\mathrm{T}$ & c & - & . & A & G & - & - & - & - & - & - & - & - & - & - & - & - & - & - & - & - & - & - & - & - & - & - & - & - & & - & - \\
\hline $\begin{array}{l}\text { Card4 } \\
\text { गN632606 javanicus } \\
\text { CEREA }\end{array}$ & - & - & c & - & - & A & G & $\mathrm{T}$ & G & - & G & A & $\mathrm{T}$ & A & A & G & $\mathrm{T}$ & A & c & A & $\mathbf{T}$ & a & A & $\mathrm{T}$ & 2. & $\mathrm{~T}$ & $\mathrm{~T}$ & a & A & $\mathrm{T}$ & G & $\mathrm{T}$ & a & a & T & & & 1 \\
\hline $\begin{array}{l}\text { WCD05971 indicus } \\
\text { WCD06380 grumiens }\end{array}$ & $\begin{array}{l}A \\
G\end{array}$ & c & $\begin{array}{l}\mathrm{c} \\
\mathrm{c}\end{array}$ & : & - & $\begin{array}{l}\mathrm{G} \\
\mathrm{A}\end{array}$ & $\begin{array}{l}\mathrm{G} \\
\mathrm{A}\end{array}$ & : & $\dot{G}$ & a & $\begin{array}{l}G \\
G\end{array}$ & $\overline{-}$ & $\overline{-}$ & $\overline{-}$ & $\overline{-}$ & $\overline{-}$ & $\overline{-}$ & $\overline{-}$ & $\begin{array}{l}- \\
-\end{array}$ & $\overline{-}$ & $\overline{-}$ & $\overline{-}$ & $\overline{-}$ & $\overline{-}$ & $\overline{-}$ & $\overline{-}$ & $\overline{-}$ & $\overline{-}$ & $\overline{-}$ & $\overline{-}$ & $\overline{-}$ & $\overline{-}$ & $\overline{-}$ & $\overline{-}$ & - & & & - \\
\hline $\begin{array}{l}\text { isol bgODB } \\
\text { WLDD6853 taurus }\end{array}$ & A & c & c & $\mathrm{T}$ & - & c & G & - & - & $\mathbf{A}$ & G & - & - & - & - & - & - & - & - & - & - & - & - & - & - & - & - & - & - & - & - & - & - & - & - & & & - \\
\hline WC012706 javanicus & $\mathbf{A}$ & c & c & $\mathrm{T}$ & . & c & G & . & . & A & G & - & - & - & - & - & - & - & - & - & - & - & - & - & - & - & - & - & - & - & - & - & - & - & - & & - & - \\
\hline $\begin{array}{l}\text { WD013996 primigenius } \\
\text { WR024818 gaurus }\end{array}$ & A & c & c & - & : & G & $\begin{array}{l}G \\
-\end{array}$ & - & : & a & G & - & - & - & - & $\overline{-}$ & - & $\overline{-}$ & - & $\overline{-}$ & $\overline{-}$ & - & $\overline{-}$ & $\overline{-}$ & $\overline{-}$ & $\overline{-}$ & $\overline{-}$ & $\overline{-}$ & - & $\overline{-}$ & - & - & - & - & - & & & - \\
\hline WC025563 mutus & G & - & c & - & - & a & A & - & G & - & G & - & - & - & - & - & - & - & - & - & - & - & - & - & - & - & - & - & - & - & - & - & - & - & - & & - & - \\
\hline 1K036020 frontalis & - & . & - & . & - & - & - & - & . & - & - & - & - & - & - & - & - & - & - & - & - & - & - & - & & - & - & - & - & - & - & - & - & - & - & & & 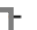 \\
\hline $\begin{array}{ll}\text { WKK } & 01 \\
\text { WKK } & 13\end{array}$ & - & - & $\begin{array}{l}\mathrm{c} \\
\mathrm{c}\end{array}$ & - & - & $\begin{array}{l}\mathrm{A} \\
\mathrm{A}\end{array}$ & $\begin{array}{l}G \\
G\end{array}$ & $\begin{array}{l}\mathrm{T} \\
\mathrm{T}\end{array}$ & $\begin{array}{l}G \\
G\end{array}$ & - & $\begin{array}{l}\mathrm{A} \\
\mathrm{G}\end{array}$ & $\begin{array}{l}\mathrm{A} \\
\mathrm{A}\end{array}$ & $\begin{array}{l}\mathrm{T} \\
\mathrm{T}\end{array}$ & $\begin{array}{l}\mathrm{A} \\
\mathrm{A}\end{array}$ & $\begin{array}{l}\mathbf{A} \\
\mathbf{A}\end{array}$ & $\begin{array}{l}G \\
G\end{array}$ & $\begin{array}{l}\mathrm{T} \\
\mathrm{T}\end{array}$ & A & c & $\begin{array}{l}\mathrm{A} \\
\mathrm{A}\end{array}$ & $\begin{array}{l}\mathrm{T} \\
\mathrm{T}\end{array}$ & A & $\begin{array}{l}\mathrm{A} \\
\mathrm{A}\end{array}$ & $\begin{array}{l}\mathrm{T} \\
\mathrm{T}\end{array}$ & 3. & $\begin{array}{l}\mathrm{T} \\
\mathrm{T}\end{array}$ & $\begin{array}{l}\mathrm{T} \\
\mathrm{T}\end{array}$ & $\begin{array}{l}\mathrm{A} \\
\mathrm{A}\end{array}$ & $\begin{array}{l}\mathrm{A} \\
\mathrm{A}\end{array}$ & $\begin{array}{l}\mathrm{T} \\
\mathrm{T}\end{array}$ & $\begin{array}{l}G \\
G\end{array}$ & 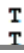 & & & $\mathrm{T}$ & & & B \\
\hline WK 19 & A & c & c & - & - & G & G & - & - & a & G & - & - & - & - & - & - & - & - & - & - & - & - & - & - & - & - & - & - & - & - & - & - & - & - & & & - \\
\hline TR 21 & A & c & c & - & - & G & G & - & - & A & G & - & - & - & - & - & - & - & - & - & - & - & - & - & - & - & - & - & - & - & - & - & - & - & - & & - & - \\
\hline TR 39 & $\mathbf{A}$ & c & c & . & . & G & G & . & . & A & G & - & - & - & - & - & - & - & - & - & - & - & - & - & - & - & - & - & - & - & - & - & - & - & - & & - & - \\
\hline
\end{tabular}

Figure 2. The section marked with a gray box is a part of a repetitive segment along $22 \mathrm{nt}$ (nucleotides). Description: the first three lines indicate the position number of the nucleotide read vertically, a reference from B. javanicus (AB915322)

Based on nucleotide sequences, two groups of pesisir cattle can be distinguished by the appearance of insertions/deletions on 16 bases (base of 15430-15446) at the beginning of $D$-loop sequence. These were only found on WK 01 and WK 13 sample and B. javanicus CERZA. The insertions/deletions were also found in the base of $15485,15516,15615-15763$, and 15793-15816. In the $D$ loop sequence, the smallest genetic distance based on the Kimura 2 Parameter model were found B. indicus and several TK and WK samples with a value of 0,000 . The most significant genetic distance values were found between Bos taurus with WK $01(0.140)$ and WK 13 (0.142).

\section{Morphological observation of pesisir cattle}

Morphological observations were taken at two locations, Way Krui (WK), Lampung and Tanah Rekah (TR), Bengkulu. Samples showed similar qualitative properties even though the color of samples tends to vary. The dominant color that was found in samples are brownish-white and yellowish-brown, other colors that were found are blackish-brown and white.

In general, the color pesisir cattle body was predominantly red with varieties of color ranging from yellowish to blackish. Pesisir cattle had blonde eyelashes, blackish-brown color on its backline, and whitish color on its leg. The hair on pesisir cattle tail was black. Pesisir cattle had a small body shape with small gumba and wattle. The shape of its horn is small and had small ears that pointing on the sideways.

\section{Discussion}

\section{Amplification and sequencing products}

Sequencing process was successfully carried out on samples from Way Krui, Lampung and Tanah Rekah, Bengkulu. Data visualization used $6 \%$ of polyacrylamide gel produced a double band with varied lengths. The varied length was caused by differences in nucleotide length of the $D$-loop due to repeated segments and deletion. This caused the size of the band of other pesisir cattle samples to be shorter than WK 01 and WK 13 sample.

There were several mutations in the DNA sequence of pesisir cattle, and those were deletion, insertion, and substitution (transversion and transition). The mutations were indicated by a fewer number of different bases in $C y t$ $b$ compared to the $D$-loop sequence. Table 1 showed that nucleotides in $C y t b$ had less substitution compared to substitutions in $D$-loop sequence. This showed that the $D$ loop sequence of pesisir cattle had a high mutation rate, while the $C y t b$ segment was more stable.

Another mutation that was found in the DNA sequence of pesisir cattle was tandem repeat segments. Repeated segments caused size variations in the D-loop. Repeated segments of 22 nt (nucleotides) with GTACATAATATTAAT and GTAATAA motives were found in WK 01 and WK 13. Pessole et al. (1999) stated that the number of repetitions and repetitive motive segments could differ between individual and species. Repeated segments were not shared by all mammalian species. Repeated segments with different motives had been found by Nijman et al. (2003) in Madura cattle with ATTACATTAATATATGTACTT repeated twice.

The repeated segment of D-loop in Bovidae families have been documented in Ovis aries along 75-76 nt in the D-loop segment (Hiendleder et al. 2002). The function of the repeated segment in D-loop was not known. The existence of repetitive segments tends to reduce the size of the genome (Avise 1994). Repeated segments also formed a strong coil structure (hairpin) this structure could inhibit the action of polymerase enzyme in vitro (Gemmel et al. 1996; Farajallah 2005). The structure of the coil rod was estimated to be one of the factors that cause low success during the amplification process. 


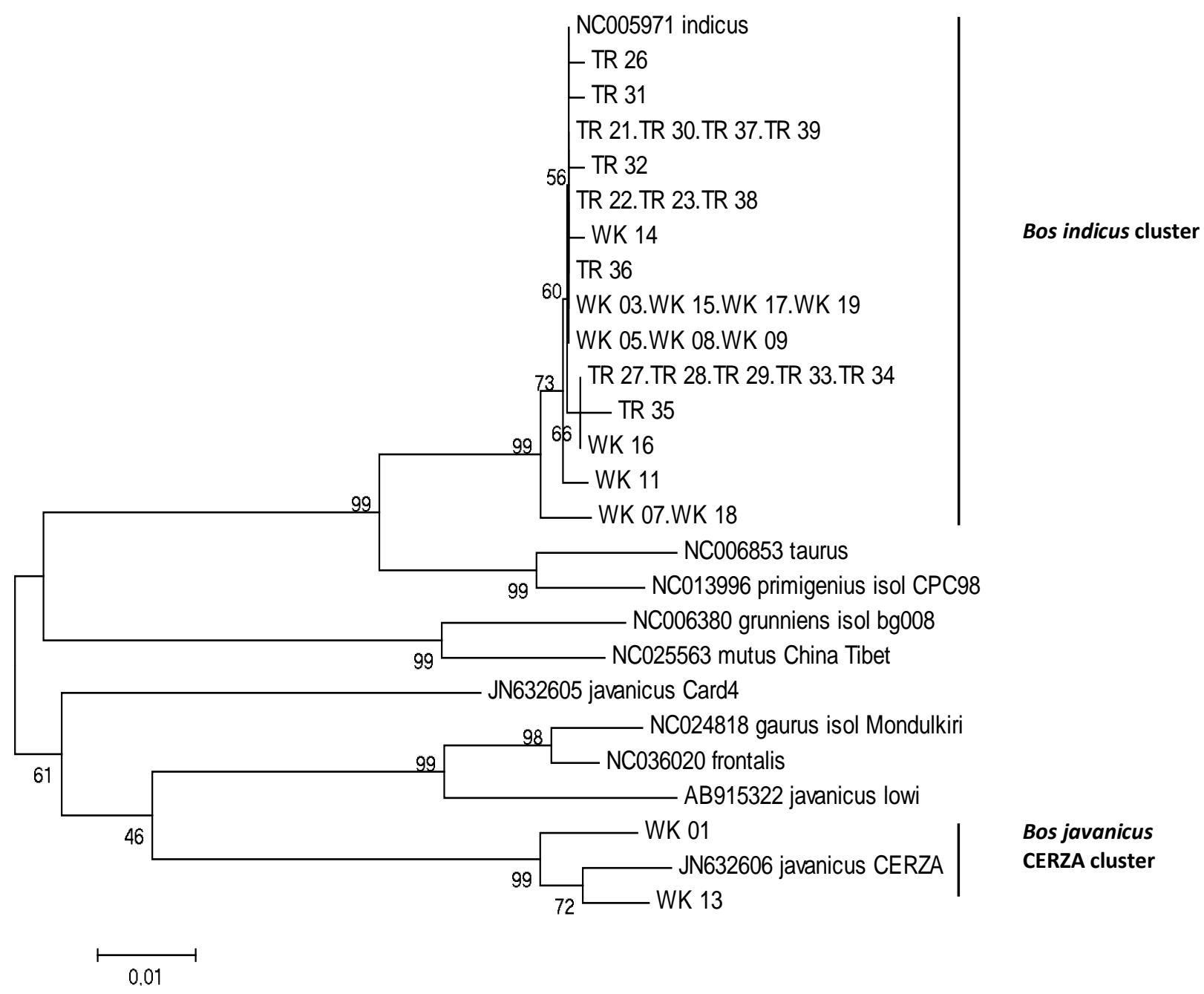

Figure 3. Results of reconstruction of phylogeny trees based on D-loop sections using the NJ method with 1000x bootstrap

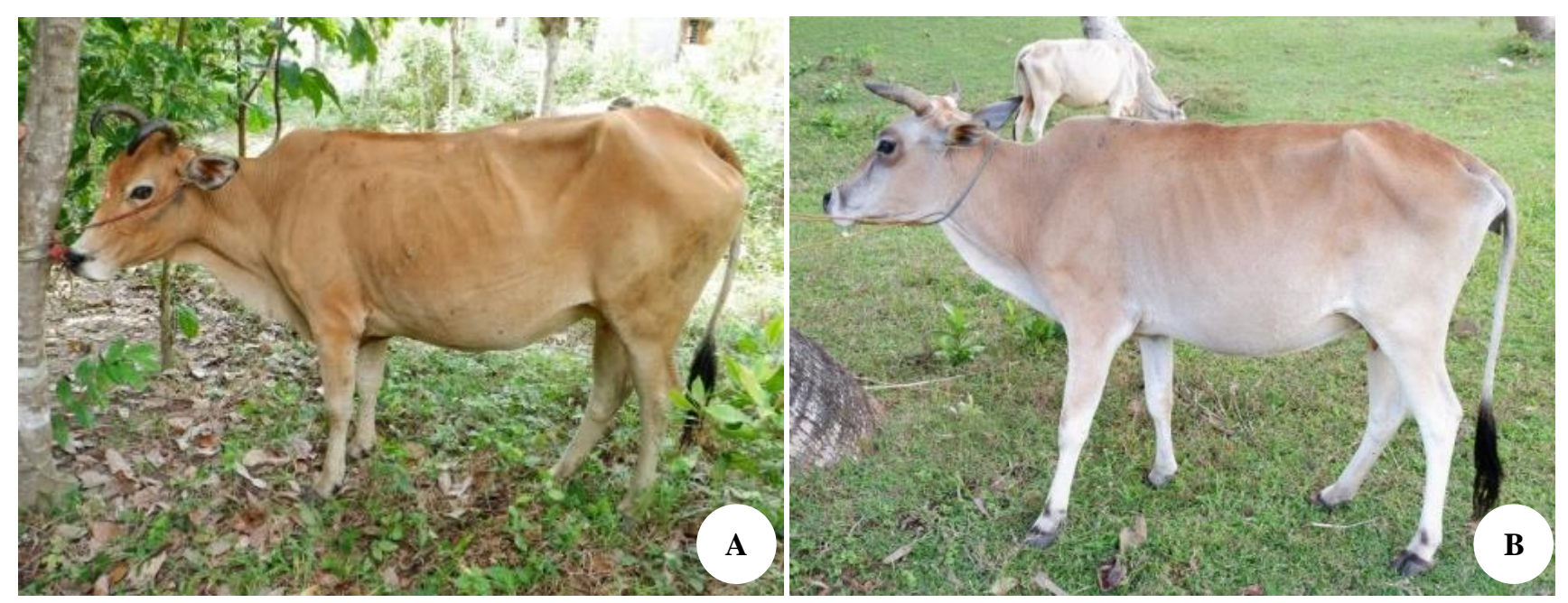

Figure 4. A. Pesisir cattle Way Krui 01. B. Pesisir cattle Way Krui 13 
Nucleotide mutations and phylogeny analysis based on the D-loop section

The result of phylogeny tree reconstruction using high D-loop mutation rates showed samples of pesisir cattle were divided into two different groups in different branches. Pesisir cattle were clustered in one branch with B. indicus (Figure 3). This result supports the analysis study of pesisir cattle kinship using mitochondrial DNA was carried out by Mohammad et al. (2009) that showed the same pattern. Cyt $b$ gene study showed that pesisir cattle from West Sumatra region were domesticated from B. indicus (Hartatik et al. 2015). This study showed that pesisir cattle have a close kinship with Aceh cattle. D-loop gene sequence study on Aceh cattle showed that Aceh cattle had a close kinship with $B$. indicus.

Pesisir cattle with sample number WK 01 and WK 03 were grouped with B. javanicus (Figures 3-4). B. javanicus sequence was from Javan banteng at Cerza Zoo, France. These data supported the results of the study that was conducted by Nijman et al. (2003), which stated that there were two types of pesisir cattle mtDNA based on the $C y t b$ segment, they were mtDNA B. javanicus and B. indicus. The appearance of two female ancestors was probably due to the small success rate of a cross between $B$. javanicus and $B$. indicus. The success rate of crossing between $B$. javanicus and $B$. indicus was around $70 \%$. The crossing between $B$. javanicus and $B$. indicus was estimated to occur since the entry of Hindu culture brought by Indians to Indonesia. Pesisir cattle were found in the western part of Sumatra, and geographically close to Java, possibly $B$. indicus and B. Javanicus interbreed and produced pesisir cattle with both mixed genotypes.

\section{Morphological analysis of pesisir cattle}

Observations of pesisir cattle were taken at two locations, Way Krui, Lampung and Tanah Rekah, Bengkulu. Samples showed relatively similar qualitative properties, even though the color of samples tends to vary. The dominant color that was found in the samples was brownish-white and yellowish-brown. Other colors that were found were blackish-brown and white (Appendix 3). The physical appearance that possessed by pesisir cattle were also found in B. indicus and some in B. javanicus. Color variations of pesisir cattle were one of the features that were also seen in $B$. javanicus, with red brick color.

Diverse colors of pesisir cattle do not found in Bali cattle, Madura cattle, and Ongole fillials (Peranakan Ongole). However, the diverse colors are relative resembles colors on Aceh cattle in Sumatra (Abdullah et al. 2008). From the patterns and kinds of colors, the results of this study almost the same as the results of Namikawa et al. (1980) which reported that Sumatran cattle (Aceh and pesisir cattle) have varieties of black, blackish-brown, yellow-brown, and white gray dominated by yellow-brown, and the Madura cattle have three of the same color as the Sumatran cattle those are black, yellowish-brown, and white-gray with yellowish-brown as dominant color.

In accordance with the genetic and phenotypic analysis of Aceh cattle which were thought to be closely related to pesisir cattle (Hartatik et al. 2015), it is assumed that pesisir cattle are domesticated from $B$. indicus and then was crossed with B. javanicus.

This study showed that there was a mixture of origin of pesisir cattle based on the matrilineal line. Pesisir cattle were grouped into two types they were $B$. indicus and $B$. javanicus. The results of this study did not show the closeness between pesisir cattle and B. taurus.

\section{REFERENCES}

Abdullah MAN, Noor RR, Handiwirawan E. 2008. Identifikasi penanda genetik daerah D-loop pada sapi aceh. J Indon Trop Anim Agric 33: 1. [Indonesian]

Adrial. 2010. Potensi sapi pesisir dan upaya pengembangannya di Sumatera Barat. Jurnal Litbang Pertanian: 29 (2). [Indonesian]

Avise JC. 1994. Molecular Markers, Natural History and Evolution. Chapman and Hall. New York.

Bradley DG, Machugh DE, Cunningham P, Loftus RT. 1996. Mitochondrial diversity and the origins of African and European cattle. Proc Natl Acad Sci USA 93: 5131-5135.

Duryadi D. 1994. Peran DNA mitokondria (mtDNA) dalam studi keragaman genetik dan biologi populasi pada hewan. J Hayati 1 , Bogor (1): 1-4. [Indonesian]

Edwards CJ, Magee DA, Park SD, McGettigan PA, Lohan AJ, Murphy A, Finlay EK, Shapiro B, Chamberlain AT, Richards MB, Bradley DG, Loftus BJ, MacHugh DE. 2010. A complete mitochondrial genome sequence from a mesolithic wild aurochs (Bos primigenius). PLoS One 5 (2): e9255. DOI: 10.1371/journal.pone.0009255.

Farajallah A. 2005. Kajian pembentukan ruas berulang dalam daerah pengontrol genom mitokondria labi-labi [Laporan Penelitian]. Bogor: Lembaga Penelitian dan Pemberdayaan Masyarakat, Institut Pertanian Bogor. [Indonesian]

Firdhausi NF. 2010. Asal usul sapi Madura berdasarkan penanda DNA mitokondria. [Thesis]. Program Pascasarjana, Institut Pertanian Bogor, Bogor. [Indonesian]

Gemmel NJ, Western PS, Watson JM, Graves JAM. 1996. Evolution of the mammalian mitochondrial control region comparisons of control region sequences between monotreme and therian mammals. Mol Biol Evol 13: 798808.

Hartatik T, Putra WBP, Volkandari SD, Sumadi. 2015. Polymorphism of mtDNA cytochrome b gene of local cattle in Indonesia. IJSFHS 3(1): 22-24.

Hassanin A, Ropiquet A. 2007. Resolving a zoological mystery: The kouprey is a real species. Proc R Soc 274: 2849-2855.

Hassanin A, Delsuc F, Ropiquet A, Hammer C, Vuuren BJV, Matthee C, Garcia MR, Catzeflis F, Areskoung V, Nguyen TT, Couloux A. 2012. Pattern and timing of diversification of Certartiodactyla (Mammalia, Laurasiatheria), as revealed by a comprehensive analysis of mitochondrial genomes. C R Biol 1631-0691.

Hiendleder S, Kaupe B, Wassmuth R, Janke A. 2002. Molecular analysis of wild and domestic sheep questions current nomenclature and provides evidence for domestication from two different subspecies. Proc R Soc Lond 269: 893-904.

Mannen H, Tsuji S, Loftus RT, Bradley DG. 1998. Mitochondrial DNA variation and evolution of Japanese black cattle (Bos taurus). Genetics 150: 1169-1175.

Martojo H. 2003. Indigenous Bali cattle: The best-suited cattle breed for sustainable small farms in Indonesia. Laboratory of Animal Breeding and Genetics, Faculty of Animal Science, Bogor Agricultural University, Bogor, Indonesia. [Indonesian]

Matsubayashi H, Hanzawa K, Kono T, Ishige T, Gakuhari T, Lagan P, Sunjoto I, Sukor JRA, Sinun W, Ahmad AH. 2014. First molecular data on Bornean banteng Bos javanicus lowi (Cetartiodactyla, Bovidae) from Sabah, Malaysian Borneo. Mammalia 78 (4): 1-9.

Mohammad K, Olsson M, Tol HTAV, Mikko S, VlamingsbBH, Andersson G, Matinez HR, Purwantara B, Paling RW, Colenbrander B, Lenstra JA. 2009. On the origin of Indonesian cattle. PLoS One 4 (5): e5490. DOI: 10.1371/journal.pone.0005490.

Na RS, Zhao YJ, Gao HJ, An TW, Huang YF, E GX. 2014. Complete mitochondrial genome of the Yakow (Bos primigenius taurus $\mathrm{x}$ Bos grunniens) in China. Mitochondrial DNA. 27 (6): 3826-3827. 
Namikawa T, Matsuda Y, Kondo K, Pangestu B, Martojo H. 1980. Blood groups and blood protein polymorphisms of different types of cattle in Indonesia. The Origin of Phylogeny of Indonesian Native Livestock (Report by Grant-in-Aid for Overseas Scientific Survey, No. 404315). The Research Group of Overseas Scientific Survey, Bogor.

Martinez-Navarro B, Karoui-Yakoub N, Oms O, Amri L, Lopez-Garcia JM, Zerai K, Hugues-Alexandre B, Moncef-Said M, Maria-Patrocinio E, Ali NBH et al. 2014. The early middle Pleistocene archeopaleontological site of Wadi Sarrat (Tunisia) and the earliest record of Bos primigenius. Quat Sci 90: 37-46

Nei M, Kumar S. 2000. Molecular Evolution and Phylogenetics. Oxford University Press, New York.

Nijman IJ, Otsen M, Verkaar ELC, Ruitjer CD, Hanekamp E, Ochieng JW, Shamshad S, Rege JEO, Hannotte O, Barwegen MW, Sulawati T, Lenstra JA. 2003. Hybridization of banteng (Bos javanicus) and zebu (Bos indicus) revealed by mitochondrial DNA, satellite DNA, AFLP microsatellites. Heredity 90:10-16.

Pessole G, Gissi C, Chirico AD, Saccone C. 1999. Nucleotide subtitution rate of mammalian mitochondrial genomes. J Mol Evol 48: 427-434.

Pénzes ZS, Csanádi GY, Kovács MG, Beer ZS. 2002. Molecular markers in ecology. Tiscia 33: 9-30.

Saladin R. 1983. Penampilan sifat-sifat produksi dan reproduksi sapi lokal Pesisir Selatan di Propinsi Sumatera Barat. [Dissertation]. Sekolah Pascasarjana, Institut Pertanian Bogor, Bogor. [Indonesian]
Sarbaini. 2004. Kajian Keragaman Karakteristik Eksternal DNA Mikrosatelit Sapi Pesisir Sumatera Barat. [Dissertation]. Sekolah Pascasarjana IPB. Bogor. [Indonesian]

Tamura K, Stecher G, Peterson D, Filipski A, Kumar S. 2013. MEGA6: Molecular Evolutionary Genetics Analysis Version 6.0. Mol Biol Evol 30 (12): 2725-2729

Tegelstrom H. 1986. Mitochondrial DNA in natural population: an improved routine for screening of genetic variation based on sensitive silver staining. Electrophoresis 7: 226-229.

Tripathi AK, Koringa PG, Jakhesara SJ, Ahir VB, Ramani UV, Bhatt VD, Sajnani MR, Patel DA, Joshi AJ, Shanmuga SJ, Rank DN, Joshi CG. 2011. A preliminary sketch of horn cancer transcriptome in Indian zebu cattle. Gene 493 (1): 124-131.

Troy CS, MacHugh DE, Bailey JF, Magee DA, Loftus RT, Cunningham P, Chamberlain AT, Sykesk BC, Bradley DG. 2001. Genetic evidence for Near-Eastern origins of European cattle. Nature 410 (6832): 10881091

Uggla CM. 2008. Investigating genetic variability within specific indigenous Indonesia cattle breed [Dissertation]. Swedish University of Agricultural Science, Uppsala, Sweden

Wang MS, Zeng Y, Wang X, Nie WH, Wang JH, Su WT, Otecko NO, Xiong ZJ, Wang S, Qu KX, Yan SQ, Yang MM, Wang W, Dong Y, Wu DD, Zhang YP. 2017. Draft genome of the gayal, Bos frontalis. Giga Sci 6 (11): 1-31. 